\title{
CRIANDO MUNDOS, PRODUZINDO SÍNTESES: EXPERIÊNCIA E TRADIÇÃO NA UMBANDA
}

Gustavo Ruiz Chiesa ${ }^{1}$

Resumo: A partir da trajetória de vida do dirigente de um terreiro de Umbanda no Rio de Janeiro, pretendo compreender a relação existente entre a experiência pessoal e a construção de uma prática religiosa. A Umbanda, pensada nos termos de uma "religião em movimento", é um objeto privilegiado para esse tipo de reflexão justamente porque valoriza o sentido criativo e a experiência do dirigente na configuração de uma prática e cosmologia religiosa. Neste caso, a experiência e criatividade individual contribuem para definir quais serão os elementos que confluem para a formação de uma tradição religiosa, direcionando o entendimento coletivo para algo que corresponda, em seus próprios termos, à "verdadeira" Umbanda.

Palavras-chave: Umbanda; Experiência; Criatividade; Transformação.

Abstract: Based on the life trajectory of the leader of a temple of Umbanda in Rio de Janeiro this work aims to understand the relationship between personal experience and the construction of a religious practice. Umbanda, thought in terms of a "religion in motion", is a privileged object for this kind of reflection precisely because they value the creative sense and experience of the leader in setting up a practice and religious cosmology. In this case, experience and individual creativity contribute to define the elements that converge to form a religious tradition, directing the collective understanding that corresponds, in their own terms, the "true" Umbanda.

Keywords: Umbanda; Experience; Creativity; Transformation.

\footnotetext{
${ }^{1}$ Doutorando em Antropologia pelo Programa de Pós-Graduação em Sociologia e Antropologia da Universidade Federal do Rio de Janeiro (PPGSA/UFRJ). Mestre em Sociologia e Antropologia pela mesma instituição. Pesquisador do Núcleo de Experimentações em Etnografia e Imagem (NEXTimagem/UFRJ).
} 